\title{
The Rivers of India
}

$\mathrm{T}$ HE material welfare of the people of India has always been in unusual measure dependent upon the amount of water available for agricultural operations at the right season. This fact chiefly led Prof. M. N. Saha to devote his recent presidential address to the National Institute of Sciences in India to "The Problem of Indian Rivers", for, as he points out, 66 per cent of the population are peasants and a further 23 per cent are villagers mainly dependent on a rural economy. While the normal rainfall suffices in parts of India to nourish the prevailing agriculture, the fact remains that this must be supplemented wherever possible by storage in 'tanks', as in most of the Deccan, by utilization of subsoil water from wells, and by the great canal systems providing irrigation water from the large rivers of the Indo-Gangetic Plain and the eastern coastal plain. The distribution of population density, therefore, may be very closely correlated with those of rainfall and irrigable land. Prof. Saha cites the estimate that of the total rainfall 60 per cent is evaporated, and of the 40 per cent which passes to the ocean only $6-8$ is used for irrigation. He pays tribute to the long-sustained interest of the Government in irrigation as leading to the huge total investment of 150 crores (more than 113 millions sterling) in new works and in repairs to old works; but he quotes the Central Irrigation Board's report that, of the 30 million acres irrigated from artificial canals, 8 million, lying chiefly in Bengal, Bihar and Orissa, are 'unproductive', that is, produce no profit for the irrigation authority.

The lateral movements of river beds on alluvial plains is of course recognized as a gradual process incessantly at work, and the same is true of the downstream migration of meanders. Nevertheless, there are reasons for believing that in northern India deep-seated crustal movements account for some of the more spectacular hydrographic changes. Prof. Saha gives examples of the effects of river change in this region. Pataliputra, the capital city of India from the sixth century B.C. until the fifth century A.D., owing its importance to its position at a focus of communications along five rivers, now lies buried $17 \mathrm{ft}$. beneath the modern Patna. Gaur, 160 miles north of Calcutta, which as Pataliputra's successor was estimated to have contained more than two million people in the fifteenth century, is now smothered in jungle. The suggestion is made that its evacuation was due to sinking, slight but sufficient to render it unhealthy. Moreover, such subsidence relative to surrounding deltajc land seems to merit investigation, since it is reported from Calcutta, where the level is said to have declined from $2 \mathrm{ft}$. to $4 \mathrm{ft}$. in the last two centuries, and this has called for pumping to assure the discharge of sewage. Finally, the well-known disastrous effects of river changes of the Ganges-Brahamaputra delta are cited, by which the eastward migration of live rivers has left the western areas seamed with channels intermittently filled, and so with abundant stagnant pools leading to malaria and decadence of the region. How far this natural process could have been prevented is uncertain; but it is claimed that in one section at least, the Burdwan division, which lost nearly half its population from malaria between
1860 and 1870, the harm was due to an artificial cause, the building of the railway embankment without proper study of the consequences to the hydrology.

In stating that construction of weirs and bridges has too often been undertaken after insufficient and too localized study of the rivers, Prof. Saha quotes Sir Francis Spring in his plea in "River 'Training and Control", that the State ought "by consistent, logical and well-organized research to learn something more definite than is now known about the physics of long reaches of rivers". This in the nineteenth century; only within the last decade has effect been given to the suggestion and so far only by two provinces. The Punjab has its Irrigation Research Institute at Lahore, and Bombay has installed a hydrodynamic research station near Poona. No such laboratory exists as yet in the eastern provinces, where the need for hydrological research would seem to be greatest.

Prof. Saha concludes his address with a striking vision of India regenerated, socially and economically, by a process of industrialization analogous to that now under way in the U.S.S.R. In reviewing the present backwardness of Indian labour conditions he attempts an assessment of energy expended, and finds the amount per head per year to be less than 90 of the units adopted (man-power 60, animal 10, steam and oil 10, electricity 7). This he contrasts with Japan, 6-8 times greater, and Norway, nearly 19 times greater. He notes the vast increase in Russian output of electricity from 15 units per head in 1919 to about 300 in 1937, with a corresponding increase in the proportion of industrial population; and he considers that this points the way for India. He then discusses the very high average cost of the half-million kilowatts of electric energy already installed in India, which represent only about $2 \cdot 5$ per cent of the hydro-electric resources, if Meares' estimate be accepted, and he cites cases of installations unduly costly owing to inadequate study. The time is therefore ripe, he submits, for a systematic survey of water-power resources following the Russian plan of attack, for he holds that cheap power will go far to eliminate the root cause of poverty in India. It may be noted, however, that he here leaves many sides of the population problem untouched.

Nevertheless, Prof. Saha has directed attention to certain facts that appear to be insufficiently appreciated : that rivers possess strong individuality in the character of their basins and in their regimens ; that the proper unit of study is the entire catchmont area ; that the uses which they offer to man-power, transport, supply for irrigation and industry - as well as the menaces of flooding and silting, are all closely interrelated ; and finally, that the dependence of the Indian people upon the rivers is so tremendous that the whole subject merits thorough investigation. In conclusion, it may be noted that the question of soil fertility is intimately bound up with those which he discusses. Systematic observation would appear to be requisite throughout each basin upon such matters as soil erosion on one hand and silting on the other, as well as on the variations in the depth of the water table and their bearing upon alkaline and other incrustations. 